\title{
PHENOLIC COMPOUNDS FROM Sedum purpureum
}

I. V. Pokotylo, L. A. Gumenyuk,

and N. N. Dykhanov

We have studied the epigeal part and roots of Sedum purpureum (purple stonecrop), family Crassulaceae, collected in various vegetation phases in the environs of the village of Kurikovka, Dnepropetrovsk oblast.

Qualitative reactions $[1,2]$ showed the presence in this plant of tanning substances, simple phenols, phenolcarboxylic acids, flavonoids, coumarins, organic acids, sterols, and sugars, which accumulate in it to the maximum extent in the vegetation period.

By paper chromatography, in the epigeal part of the purple stonecrop we found not less than 22 substances of phenolic nature, and by preparative chromatography on Kapron from an aqueous ethanolic extract of the same part of the plant we isolated the total flavonoids $(0.6 \%)$. These we re rechromatographed on a column of alumina. On elution with water we isolated a substance with the composition $\mathrm{C}_{12} \mathrm{H}_{16} \mathrm{O}_{7}$, mp $151-152^{\circ} \mathrm{C}$ (aqueous acetone, $\left.1: 1\right)[\alpha]_{\mathrm{D}}^{20}-59^{\circ}, \mathrm{R}_{f} 0.92$ in the ethyl acetate-formic acid-water $(10: 2: 3)$ system and 0.74 in $15 \%$ acetic acid.

From the products of acid (2\% sulfuric acid) and enzymatic (rhamnodiastase) hydrolysis of this substance we isolated $\mathrm{D}$-glucose and an aglycone. The aglycone had the composition $\mathrm{C}_{6} \mathrm{H}_{6} \mathrm{O}_{2}, \mathrm{mp} 170-172^{\circ} \mathrm{C}$; its acetyl derivative $\mathrm{C}_{10} \mathrm{H}_{10} \mathrm{O}_{4}$ had $\mathrm{mp} 123-125^{\circ} \mathrm{C}$ and its methyl derivative $\mathrm{C}_{8} \mathrm{H}_{10} \mathrm{O}_{2}$ had mp $58-60^{\circ} \mathrm{C}$, i.e., the aglycone was identical with hydroquinone [3].

The carbohydrate component (D-glucose) is present in the pyranose form and is bound to the hydroquinone by a $\beta$-linkage, and is shown by absorption bands in the IR spectrum at 790,900 , and $920 \mathrm{~cm}^{-1}$.

Thus, from the results of physicochemical analysis and the absence of a depression of the melting point of a mixture with an authentic sample, the compound isolated was identified as hydroquinone $\mathrm{O}-\beta-\Gamma-$ glucopy ranoside (arbutin).

\section{LITERATURE CITED}

1. L. A. Gumenyuk, N. N. Dykhanov, and V. S. Batyuk, Khim. Prirodn. Soedin., 391 (1972).

2. V. M. Shelud'ko and Yu. I. Kolesnichenko, Practical Aid to Pharmacognosy [in Ukrainian], Kiev (1969), p. 27.

3. Ya. K. Yatsyuk and S. S. Lyashenko, Chemical Investigations in Pharmacy [in Russian], Kiev (1970). p. 164.

4. I. P. Kovalev and V. I. Litvinenko, Khim. Prirodn. Soedin., 233 (1965).

The Poltava Medical Stomatological Institute. Translated from Khimiya Prirodnykh Soedinenit, No. 2, pp. 252-253, March-April, 1974. Original article submitted November 11, 1973.

(c) 1975 Plenum Publishing Corporation, 227 West 17th Street, New York, N.Y. 10011. No part of this publication may be reproduced, stored in a retrieval system, or transmitted, in any form or by any means, electronic, mechanical, photocopying, microfilming, recording or otherwise, without written permission of the publisher. A copy of this article is available from the publisher for $\$ 15.00$. 